\title{
Rice Pi-ta gene Confers Resistance to the Major Pathotypes of the Rice Blast Fungus in the United States
}

\author{
Yulin Jia, Zhonghua Wang, Robert G. Fjellstrom, Karen A. K. Moldenhauer, \\ Md A. Azam, James Correll, Fleet N. Lee, Yingwu Xia, and J. Neil Rutger
}

First, second, and ninth authors: U.S. Department of Agriculture-Agricultural Research Service (USDA-ARS) Dale Bumpers National Rice Research Center, Stuttgart, AR 72160; second and eighth authors: Institute of Nuclear Agricultural Sciences, Zhejiang University, Hangzhou, P.R. China 310029; third author: USDA-ARS Rice Research Unit, Beaumont, TX 77713; fourth and seventh authors: Rice Research and Extension Center, University of Arkansas, Stuttgart 72160; fifth author: Bangladesh Institute of Nuclear Agriculture, Mymensingh 2200, Bangladesh; and sixth author: Department of Plant Pathology, University of Arkansas, Fayetteville 72701. Accepted for publication 7 October 2003.

\section{ABSTRACT}

Jia, Y., Wang, Z., Fjellstrom, R. G., Moldenhauer, K. A. K., Azam, M. A., Correll, J., Lee, F. N., Xia, Y., and Rutger, J. N. 2004. Rice Pi-ta gene confers resistance to the major pathotypes of the rice blast fungus in the United States. Phytopathology 94:296-301.

The Pi-ta gene in rice prevents the infection by Magnaporthe grisea strains containing the AVR-Pita avirulence gene. The presence of Pi-ta in rice cultivars was correlated completely with resistance to two major pathotypes, IB-49 and IC-17, common in the U.S. blast pathogen population. The inheritance of resistance to IC-17 was investigated further using a marker for the resistant $\mathrm{Pi}$-ta allele in an $\mathrm{F}_{2}$ population of 1,345 progeny from a cross of cv. Katy with experimental line RU9101001 possessing and lacking, respectively, the $P i$-ta resistance gene. Resistance to IC-17 was conferred by a single dominant gene and Pi-ta was not detected in susceptible individuals. A second $F_{2}$ population of 377 individuals from a reciprocal cross between Katy and RU9101001 was used to verify the conclusion that resistance to IC-17 was conferred by a single dominant gene. In this cross, individuals resistant to IC-17 also were resistant to IB-49. The presence of $P i$-ta and resistance to IB-49 also was correlated with additional crosses between 'Kaybonnet' and 'M-204', which also possess and lack $P i-t a$, respectively. A pair of primers that specifically amplified a susceptible pi-ta allele was developed to verify the absence of $P i$-ta. We suggest that $P i$-ta is responsible for resistance to IB-49 and IC-17 and that both races contain AVR-Pita genes.

Additional keywords: Oryza sativa, Pyricularia.
Plant resistance genes play central roles in crop protection. Understanding molecular mechanisms of resistance should accelerate the development of resistant cultivars $(8,12,38)$. Rice blast, caused by the fungal pathogen Magnaporthe grisea (Herbert) Borr. (anamorph Pyricularia oryza Cavara), is one of the bestcharacterized models for understanding molecular mechanisms of natural defense response (41). Resistance to infection by $M$. grisea follows a classic gene-for-gene theory (35). The Pi-b and Pi-ta genes are two major blast resistance $(R)$ genes that have been characterized molecularly $(2,45)$. The rice (Oryza sativa) Pi-b gene is a member of a small gene family and encodes a predicted nucleotide binding site leucine-rich repeat (NBS-LRR) protein (45). Pi-ta, a single-copy gene, encodes a putative cytoplasmic NBS-type receptor that appears to bind the putative processed $A V R$-Pita gene product to activate the defense response $(2,16,17$, 33 ). Four haplotypes, one conferring resistance and three conferring susceptibility, have been uncovered at the Pi-ta locus in rice germ plasm (16). AVR-Pita is a putative metalloprotease possessing properties similar to bacterial effector proteins (17). The cloned Pi-ta/AVR-Pita pair in the rice blast system provides an excellent tool for understanding molecular mechanisms of plant disease resistance $(2,16,17,33)$. Molecular characterization of rice blast $R$ genes has been enhanced by the completion of

Corresponding author: Y. Jia; E-mail address: yjia@spa.ars.usda.gov

\section{Publication no. P-2004-0115-02R}

This article is in the public domain and not copyrightable. It may be freely reprinted with customary crediting of the source. The American Phytopathological Society, 2004 rough drafts of the rice genome, an integrated physical and genetic map, and a large expressed gene map $(5,11,46,48)$.

Rice blast is one of the most destructive diseases of rice worldwide (24). Incorporating major resistance genes through markerassisted selection (MAS) has been successful in controlling the disease (14). To date, over 20 major resistance genes and 10 quantitative trait loci for blast have been described and some of them have been tagged for MAS $(4,10,13,15,21,23,26,32,36$, $37,39,44,49,50)$. Three blast-resistance genes recently have been pyramided into a commercial rice cultivar by MAS (14). Research on Pi-ta/AVR-Pita has led to the development of three markers for the resistant Pi-ta allele for MAS (19), but markers for the susceptible pi-ta allele have not been developed.

$P i$ - $t a$ has been introgressed into diverse japonica rice cultivars to control rice blast disease $(2,20,22,31,34)$. The $P i$-ta gene initially was mapped between random amplified polymorphic DNA markers SP4B9 and SP9F3 and was cloned by map-based cloning (2). The $P i-t a^{2}$ gene was mapped among restriction fragment length polymorphism (RFLP) markers XNP 088, 079, and Rubss (34). To date, it has been unclear whether the defense against $M$. grisea isolates involves the combined actions of both the $P i-t a$ and $P i-t a^{2}$ genes or if the difference in resistance spectrum was due to different $M$. grisea races that were used for pathogenicity assays in several rice-growing countries. The $\mathrm{Pi}$-ta gene was reported to be required for the function of the Pi-ta gene and both genes were inseparable in $1,000 \mathrm{~F}_{2}$ individuals of a cross with these two genes (23).

Severe outbreaks of rice blast disease occurred in the 1980s in the southern United States. Katy, a U.S. rice cultivar, has had effective resistance to the blast disease since its release in the late 80 's (29). Katy continues to have effective resistance to blast in 
Arkansas. Arkansas is the largest rice-producing state, where $49 \%$ of U.S. rice is grown (30). The presence of the Pi-ta gene in Katy was verified by the markers for the resistant $P i$-ta allele and presumably was transferred from a Vietnamese cultivar, Tetep, through classical plant breeding $(19,29)$. Surveys have indicated that races IB-49 and IC-17 are predominant in Arkansas (47). Previously, a factor in Katy conferring resistance to IB-49 and IC17 was determined to be a single gene trait (28). However, it still is unclear whether or not Pi-ta in Katy is responsible for resistance to both races. The resistance factor to IB-49 previously was mapped between two simple sequence repeat (SSR) markers RM155 and RM7102 near the centromere $(5,9)$. The location of the Pi-ta gene with respect to RM155 and RM7102 has not been determined.

Rapid changes of avirulence genes in M. grisea have challenged the effectiveness of a single $R$ gene (41). Determination of the presence of $\mathrm{Pi}$-ta in U.S. rice cultivars not only facilitates the development of blast resistant cultivars by MAS but also allows the prediction of stability of resistance in deployed rice cultivars. The objectives of this study were to (i) determine whether $\mathrm{Pi}$-ta confers resistance to races IB-49 and IC-17 using two large $F_{2}$ mapping populations, (ii) develop a marker for the susceptible $p i$ ta allele, and (iii) determine the map position of the Pi-ta gene using SSR markers RM155 and RM7102.

\section{MATERIALS AND METHODS}

Plant materials and growth. A set of rice cultivars reportedly containing $P i$ - $t a / P i$ - $t a^{2}$ and lacking both genes was used to determine the correlation of the Pi-ta gene with resistance to predominant U.S. pathotypes. Twenty rice cultivars for this study were provided by the National Small Grains Collection, Aberdeen, ID, U.S. Department of Agriculture-Agriculture Research Service (USDA-ARS) and were evaluated for resistance and presence of $P i$-ta (Table 1). Rice cv. Katy (Pi-ta/Pi-ta) is resistant to races IB49 and IC-17 of $M$. grisea and contains the Pi-ta gene (2,3, 19,28,29). The rice experimental line RU9101001 (pi-ta/pi-ta) is susceptible to IB-49 and IC-17 (Z. Wang and Y. Jia, unpublished data). An $\mathrm{F}_{2}$ population of 1,345 individuals from the cross of RU9101001 with Katy was used to determine the association of the resistance to IC-17 and the Pi-ta gene. A reciprocal cross of $377 \mathrm{~F}_{2}$ individuals was evaluated for $\mathrm{P} i$-ta presence and resistance to IB-49 and IC-17. $\mathrm{F}_{2}: \mathrm{F}_{3}$ families were produced at the USDAARS Dale Bumper National Rice Research Center.

$\mathrm{Cv}$. Kaybonnet $(\mathrm{Pi}-\mathrm{ta} / \mathrm{Pi}$-ta) is resistant to IB-49. Cvs. M-204 and Maybelle (pi-ta/pi-ta) are susceptible to IB-49 (Z. Wang and Y. Jia, unpublished data). An $\mathrm{F}_{2}$ population of 440 individuals of a cross between Kaybonnet and M-204 and an $\mathrm{F}_{2}$ population of 335 individuals of a Kaybonnet and Maybelle cross were used to determine the map position of the resistance factor to IB-49 and IC-17.

Seeds were pregerminated on moistened filter paper for 2 days at $30^{\circ} \mathrm{C}$. Plants were grown in a greenhouse at 24 to $30^{\circ} \mathrm{C}$ with $16 \mathrm{~h}$ of light for 2 to 4 weeks until plants were at the four-leaf stage, at which point they were used for disease reaction testing and for DNA isolation.

Disease reactions. $M$. grisea races IC-17 (isolate ZN57) and IB-49 (isolate ZN61) from the southern United States were used as inoculum (6). Disease reactions of $F_{2}$ populations and $F_{3}$ families were performed using standard pathogenicity assays (42), except for $F_{2}$ progeny from a cross of Katy with RU9101001. For standard pathogenicity assays, plants were inoculated with spore suspensions $\left(2.5 \times 10^{5}\right.$ spores $\left./ \mathrm{ml}\right)$ at $15 \mathrm{ml} /$ tray using an airbrush. Plants were incubated in a dark dew chamber for $24 \mathrm{~h}$ at $25^{\circ} \mathrm{C}$. After $24 \mathrm{~h}$, the plants were returned to the greenhouse. Disease reactions were assessed 7 days after inoculation. A resistant reaction was based on no visible infection and no conidia produced from inoculated tissue. A susceptible reaction was based on a lesion size greater than $3 \mathrm{~mm}$ in length and the presence of conidia in the lesions (42).

Detached leaf inoculation was used to inoculate $377 \mathrm{~F}_{2}$ progeny from a cross of Katy with RU9101001 with both IB-49 and IC-17 by a method described by Jia et al. (18) with the following modifications. Leaves were detached at the tiller stage (7). For one set, four separate leaf segments of each plant were inoculated with five $10-\mu l$ droplets of IB-49 conidial suspension $\left(5.0 \times 10^{4}\right.$ spores $\left./ \mathrm{ml}\right)$. For another set; four separate leaf segments of the same plant were inoculated with five $10-\mu$ d droplets of IC-17 conidial suspension $\left(5.0 \times 10^{4}\right.$ spores $\left./ \mathrm{ml}\right)(18)$.

Disease reactions of 20 plants of each $\mathrm{F}_{3}$ family were evaluated to confirm the genotypes of $F_{2}$ individuals. In each $F_{3}$ family, if all individuals were resistant, the genotype of $\mathrm{F}_{2}$ was designated $\mathrm{Pi}$-ta/Pi-ta; if all individuals were susceptible, the genotype of $\mathrm{F}_{2}$ was designated pi-ta/pi-ta; if both resistant and susceptible individuals were observed, then the genotype of $\mathrm{F}_{2}$ was $P i$-ta/pi-ta.

DNA extraction. Rice leaves were frozen in liquid nitrogen and stored at $-80^{\circ} \mathrm{C}$. DNA was extracted from frozen leaves using DNeasy Plant Mini Kit (Qiagen, Valencia, CA) according to the manufacturer's instructions or a cetyltrimethylammonium bromide (CTAB) technique (9). For the CTAB technique, $900 \mu \mathrm{l}$ of PEX/CTAB extraction buffer $(6.25 \mathrm{mM}$ potassium ethyl xanthogenate, $0.5 \%$ CTAB, $700 \mathrm{mM} \mathrm{NaCl}, 10 \mathrm{mM}$ EDTA, and $100 \mathrm{mM}$ Tris, $\mathrm{pH}$ 7.5) was added to lyophilized leaf tissue cut up into small pieces and put in 2-ml Eppendorf tubes, then lightly vortexed. The tubes were placed in a $65^{\circ} \mathrm{C}$ water bath for $1 \mathrm{~h}$, mixed with $700 \mu \mathrm{l}$ of $100 \%$ chloroform, and centrifuged for $10 \mathrm{~min}$. The aqueous layer was collected and $800 \mu \mathrm{l}$ of isopropanol was added to precipitate the nucleic acids. Nucleic acid pellets were washed with $400 \mu \mathrm{l}$ of $100 \%$ ethanol, dried, and resuspended in $100 \mu \mathrm{l}$ of Tris-EDTA buffer (10 mM Tris, pH 7.5, and 0.5 mM EDTA).

The Pi-ta gene markers. Primers for the resistant $P i$ - $t a$ allele YL155 (5'-AGCAGGTTATAAGCTAGGCC-3')/YL87 (5'-CTACCAACAAGTTCATCAAA-3') (19) and YL100 (5'-CAATGCCGAGTGTGCAAAGG-3')/YL102 (5'-TCAGGTTGAAGATGCA-

TABLE 1. Resistance to predominant pathotypes of Magnaporthe grisea is correlated completely with the presence of the $P i$ - $t a$ gene in rice cultivars

\begin{tabular}{|c|c|c|c|c|}
\hline Cultivar & Reaction $^{\mathrm{a}}$ & $P i$-ta present ${ }^{\mathrm{b}}$ & Genotype $^{c}$ & Reference \\
\hline Drew & $\mathrm{R}$ & Yes & $P i-t a / P i-t a^{2}$ & (16) \\
\hline El Paso 144 & $\mathrm{R}$ & Yes & $P i-t a$ & (16) \\
\hline IR-36 & $\mathrm{R}$ & Yes & $P i-t a$ & (15) \\
\hline IR-64 & $\mathrm{R}$ & Yes & $P i-t a$ & (15) \\
\hline Katy & $\mathrm{R}$ & Yes & $P i-t a / P i-t a^{2}$ & $(2,16,19)$ \\
\hline PI-1 & $\mathrm{R}$ & Yes & Pi-ta & (34) \\
\hline PI-2 & $\mathrm{R}$ & Yes & $P i-t a$ & (34) \\
\hline PI-4 & $\mathrm{R}$ & Yes & $P i-t a^{2}$ & (34) \\
\hline PI-5 & $\mathrm{R}$ & Yes & $P i-t a^{2}$ & (34) \\
\hline Reiho & $\mathrm{R}$ & Yes & $P i-t a / P i-t a^{2}$ & $(2,16)$ \\
\hline Shimokita & $\mathrm{R}$ & Yes & Pi-ta & $(21,30)$ \\
\hline Tadukan & $\mathrm{R}$ & Yes & $P i-t a / P i-t a^{2}$ & $(2,16,34)$ \\
\hline Tetep & $\mathrm{R}$ & Yes & $P i-t a / P i-t a^{2}$ & $(2,49)$ \\
\hline C101A51 & $\mathrm{S}$ & No & No & $(2,14,15)$ \\
\hline CO39 & S & No & No & $(4,15)$ \\
\hline Fujiminori & S & No & No & (15) \\
\hline Norin-29 & $\mathrm{S}$ & No & No & (15) \\
\hline Reimei & $S$ & No & No & (15) \\
\hline Somewake & $\mathrm{S}$ & No & No & (15) \\
\hline Tsuyuake & S & No & No & $(15,16)$ \\
\hline
\end{tabular}

a Disease reactions were determined by standard inoculation with IC-17 and IB-49 in different experiments; $\mathrm{R}=$ resistant and $\mathrm{S}=$ susceptible. The same disease reaction was obtained from IC-17 and IB-49.

b $\mathrm{Pi}$-ta presence was determined by the use of a marker for the resistant Pi-ta allele YL155/YL87 and the absence of Pi-ta was verified by the use of a marker for the susceptible $p i$-ta allele YL183/YL87; $P i$-ta presence $=$ yes and $P i$-ta/Pi-ta $a^{2}$ absence $=$ no.

c The presence of $P i$-ta was determined by pathogenicity assays using different $M$. grisea isolates in different laboratories. 
TAGC-3'), and primers for the susceptible pi-ta allele YL183 (5'AGCAGGTTATAAGCTAGCTAT-3')/YL87 (5'-CTACCAACAAGTTCATCAAA-3') were developed to detect the Pi-ta/pi-ta alleles from genomic DNAs of $F_{2}$ and $F_{3}$ plants by polymerase chain reaction (PCR). Each PCR was performed with 5 to $10 \mathrm{ng}$ of total DNA, $5 \mu$ of Taq PCR master mix ( $2 \times$ concentrated, containing 0.5 unit of Taq DNA polymerase, and Qiagen PCR buffer with $3 \mathrm{mmol}$ of $\mathrm{MgCl}_{2}$ and $400 \mu \mathrm{mol}$ of each dNTP), $1 \mu \mathrm{l}$ of $25 \mathrm{mM}$ $\mathrm{MgCl}_{2}$, and $0.5 \mu \mathrm{l}$ of each primer in a final reaction volume of $10 \mu \mathrm{l}$. The PCRs were performed in a Peltier Thermal Cycler (PTC-20; MJ Research, Waltham, MA) with the following program: $3 \mathrm{~min}$ at $95^{\circ} \mathrm{C}$ for an initial denaturation, followed by 29 cycles of $30 \mathrm{~s}$ at $95^{\circ} \mathrm{C}, 30 \mathrm{~s}$ at $55^{\circ} \mathrm{C}, 30 \mathrm{~s}$ each at $72^{\circ} \mathrm{C}$; and a final extension at $72^{\circ} \mathrm{C}$ for $7 \mathrm{~min}$. The PCR products $(10 \mu \mathrm{l})$ were separated by electrophoresis on $1.5 \%$ (wt/vol) agarose gels in $1 \times$ Trisborate-EDTA (TBE) buffer, stained in ethidium bromide, and visualized using an ultraviolet transilluminator. All PCR reactions for each sample were repeated at least once with the same result.

SSR amplification and marker analysis. Three mapped SSR markers-OSM89, derived from GenBank accession D17586 and mapping to the same position as RM101 (40); OSM 91, derived from RM155 (40), and RM7102 (27), located near RFLP marker Y6854R on the long arm near the centromere of chromosome 12 -were amplified following published protocols $(1,9)$. Genomic DNA from resistant Kaybonnet, M204, Maybelle, and their progenies were used as templates for PCR using the SSR markers OSM89 (forward: 5'-TTGGTCAAAGTTAGCCATGGAGGG-3' and reverse: 5'-TTTGAACCGGGTGGCCCACATG-3'), RM155/ OSM91 (forward: 5'-ACCGTCGCTCCCTTCCAGGGC-3' and reverse: 5'-CTCCACGGTGAGCGGTGGCAG-3'), and RM7102 (forward: 5'-TTGAGAGCGTTTTTAGGATG-3' and reverse: 5'TCGGTTTACTTGGTTACTCG-3') (9). PCR products were analyzed by vertical gel electrophoresis or capillary electrophoresis.
Amplification products were loaded on nondenaturing $8 \%$ polyacrylamide (29:1, acryl/bis) $1 \times$ TBE gels, run overnight at $220 \mathrm{~V}$, and stained directly on separated, water-rinsed plates for $10 \mathrm{~min}$ with a 50-ml solution of Gelstar (BioWhittaker Medical Applications, Rockland, MA) nucleic acid stain diluted 10,000-fold in $1 \times$ TBE. Marker genotypes were determined and compared with disease reactions to estimate the linkage between the $P i$-ta gene and SSRs, with genetic distance reported as a recombination fraction (Morgan map units) using desktop computer software, Map Manager QTX (25), to estimate genetic distances.

\section{RESULTS}

Resistance to two major U.S. pathotypes was conditioned by the Pi-ta gene. Disease reactions of a set of rice cultivars to two major U.S. races, IB-49 and IC-17, were evaluated. All cultivars containing $P i$-ta/Pi-ta $a^{2}$ were resistant to both pathotypes and the presence of the Pi-ta gene was detected only in resistant cultivars and not in susceptible cultivars (Table 1).

To investigate whether the $P i$-ta gene was responsible for resistance to IC-17, an $\mathrm{F}_{2}$ population of 1,345 progeny from a cross of RU9101001 with Katy, segregating for the Pi-ta gene, was used to investigate the inheritance of resistance. The disease reaction of each $\mathrm{F}_{2}$ progeny was determined by standard pathogenicity assays (Table 2). The genotype of each $\mathrm{F}_{2}$ progeny, whether homozygote or heterozygote for $\mathrm{Pi}$-ta, was determined by $\mathrm{F}_{3}$ progeny analysis (Table 2; and data on disease reaction of $\mathrm{F}_{3}$ progeny, data not shown). A 1:2:1 ratio of homozygous resistant/heterozygous resistant/homozygous susceptible was observed (Table 2). The segregation data support the model that resistance in Katy to IC17 is conferred by one single dominant gene (Table 2). The presence of the PCR product, estimated to be 1,042 bp, indicates the presence of the Pi-ta gene (Fig. 1A). All resistant $\mathrm{F}_{2}$ individuals

TABLE 2. Cosegregation ratios of resistance to two Magnaporthe grisea races and genotypes in segregating $\mathrm{F}_{2}$ rice populations ${ }^{\mathrm{a}}$

\begin{tabular}{|c|c|c|c|c|c|c|c|}
\hline \multirow[b]{2}{*}{ Pedigree } & \multirow[b]{2}{*}{ Race } & \multirow[b]{2}{*}{ Total } & \multicolumn{3}{|c|}{ Genotypes of $F_{2}$ progeny } & \multirow[b]{2}{*}{$\chi^{2 b}$} & \multirow[b]{2}{*}{$P$} \\
\hline & & & $P i-t a / P i-t a(\mathrm{R})$ & Pi-ta/pi-ta (Rs) & $p i-t a / p i-t a(\mathrm{~S})$ & & \\
\hline RU9101001/Katy ${ }^{c}$ & IC-17 & 1,345 & 335 & 686 & 324 & 0.722 & 0.423 \\
\hline \multirow[t]{2}{*}{ Katy/RU9101001 ${ }^{\mathrm{d}}$} & IC-17 & 377 & 90 & 200 & 87 & 1.450 & 0.170 \\
\hline & IB-49 & 377 & 90 & 200 & 87 & 1.450 & 0.170 \\
\hline
\end{tabular}

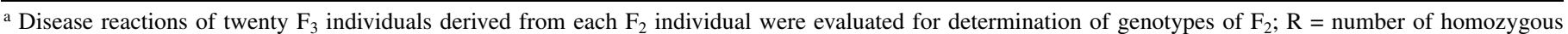
resistant; Rs = number of heterozygous resistant, $\mathrm{S}=$ number of homozygous susceptible.

b Ratio of 1:2:1 (homozygous resistant/heterozygous resistant/homozygous susceptible) was expected.

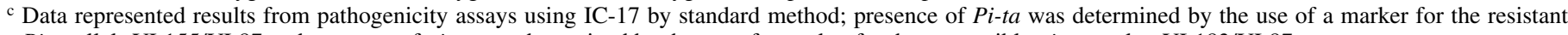

Pi-ta allele YL155/YL87 and presence of pi-ta was determined by the use of a marker for the susceptible pi-ta marker YL183/YL87.

${ }^{\mathrm{d}}$ Data represented results from pathogenicity assays of IB-49 and IC-17 by detached leaf method.

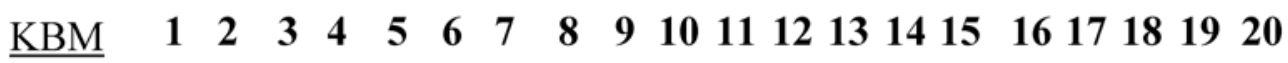

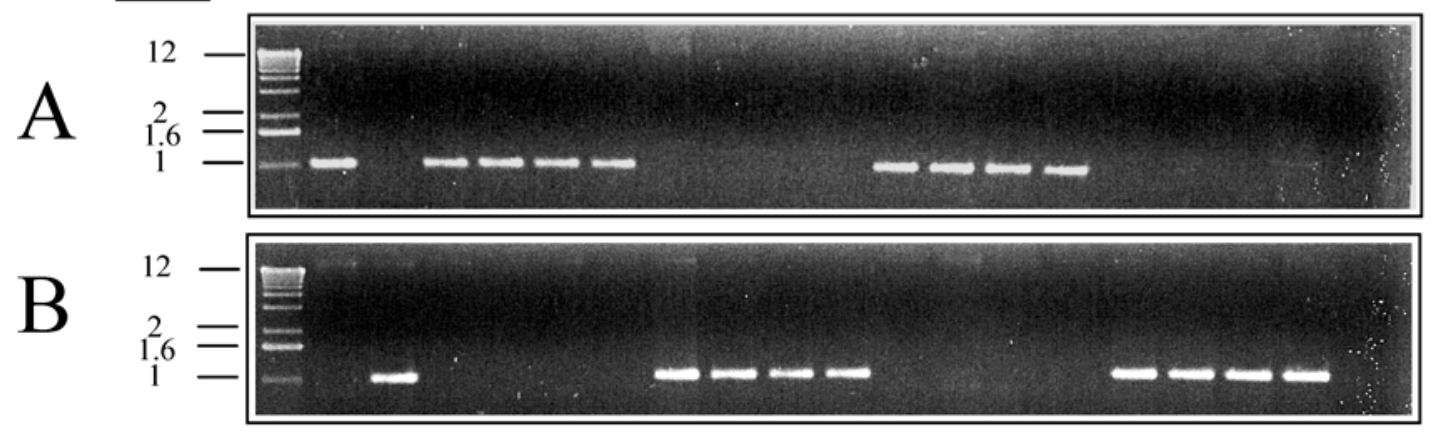

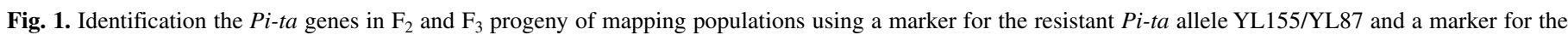

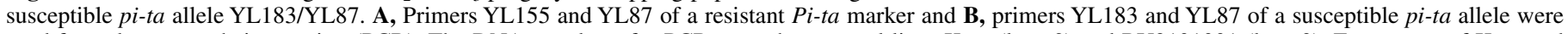

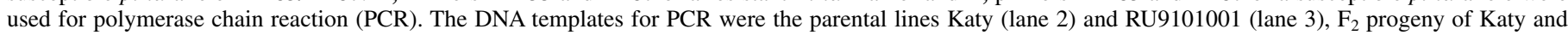

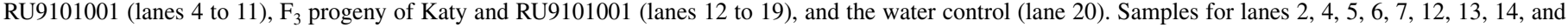

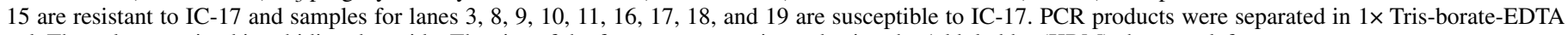
gel. The gel was stained in ethidium bromide. The size of the fragment was estimated using the 1-kb ladder (KBM) shown at left. 
contained $\mathrm{Pi}$-ta, whereas all susceptible $\mathrm{F}_{2}$ individuals did not, suggesting that $P i$-ta was responsible for resistance to IC-17 (Fig. 1A; Table 2).

An $F_{2}$ population of 377 individuals from a RU9101001/Katy reciprocal cross was used to confirm the inheritance of resistance to IC-17. Disease reactions of $F_{2}$ progeny to IC-17 were determined by a detached leaf method. In another test, the same disease reaction to IB-49 for each $\mathrm{F}_{2}$ progeny also was determined by a detached leaf test. The genotype of each $\mathrm{F}_{2}$ progeny, whether homozygote or heterozygote for $\mathrm{Pi}-\mathrm{ta}$, also was determined by $\mathrm{F}_{3}$ progeny analysis (Table 2; data on disease reaction of each $\mathrm{F}_{3}$ progeny, data not shown). A ratio of 1:2:1 homozygous resistant/ heterozygous resistant/homozygous susceptible was detected in both races IC-17 and IB-49 (Table 2). The presence of the Pi-ta gene was not detected in susceptible individuals and was detected only in resistant individuals in $F_{2}$ populations and $F_{3}$ families, confirming that $\mathrm{Pi}$-ta confers resistance to both IC-17 and IB-49 (Fig. 1A, Table 2).

A marker for the susceptible pi-ta gene. A marker for the susceptible pi-ta allele was developed to verify the absence of the resistant Pi-ta allele in all samples not containing Pi-ta PCR products. A pair of primers specific to a susceptible pi-ta haplotype was designed to verify that the absence of PCR amplification products in susceptible individuals was not due to a problem with the genomic DNA sample. Primer YL183, specific to a susceptible pi-ta haplotype, differed from a resistant $\mathrm{Pi}$-ta haplotype at the last four nucleotides, 5'-CTAT-3' (YL183) and 5'-GCC-3' (YL155). A portion of the susceptible pi-ta allele (1,043 bp, GenBank accession no. AY196754) was amplified from susceptible individuals and not from resistant ones by the primers YL183 and YL87 (Fig. 1B).

TABLE 3. Mapping the Pi-ta gene in rice using simple sequence repeat (SSR) markers

\begin{tabular}{lcc}
\hline Cross, SSR marker & $\begin{array}{c}\text { No. of } \\
\text { recombinant plants }\end{array}$ & $\begin{array}{c}\text { Genetic distance } \\
(\mathrm{cM})\end{array}$ \\
\hline Maybelle/Kaybonnet $\mathrm{F}_{2}$ & & \\
OSM89 & $21 / 334$ & 3.2 \\
RM155 & $5 / 335$ & 0.8 \\
RM7102 & $7 / 334$ & 1.1 \\
Kaybonnet/M-204 F2 & & \\
OSM89 & $13 / 440$ & 2.4 \\
RM7102 & $5 / 437$ & 1.3 \\
\hline
\end{tabular}

a Recombinant plants were determined if an individual was resistant without SSR markers linked to Pi-ta or susceptible without SSR markers linked to pi-ta in a plant.
Map position of the Pi-ta gene. Two crosses involving Kaybonnet, another $\mathrm{Pi}$-ta-containing rice cultivar, were used to map the Pi-ta gene using codominant SSR markers OSM89, RM155, and RM7102. The markers for the Pi-ta and pi-ta genes also were used to determine the presence or absence of the Pi-ta genes in both $\mathrm{F}_{2}$ progeny (Table 3 ). Again, the presence of $P i$-ta was identified only in resistant individuals. The Pi-ta gene was mapped between RM155 and RM7102 with $0.8 \mathrm{cM}$ to RM155 at one side and $1.2 \mathrm{cM}$ to RM7102 at another side (Table 3; Fig. 2). From the crosses of Katy and RU9101001 and its reciprocal, however, two $\mathrm{F}_{2}$ individuals containing $P i$-ta were susceptible and two $\mathrm{F}_{2}$ individuals lacking Pi-ta were resistant to both IB-49 and IC-17. These individuals were evaluated further using flanking markers RM155 and RM7102. Susceptible individuals contained homozygous susceptible alleles of both RM155 and RM7102 and resistant individuals contained homozygous resistant alleles of both RM155 and RM7102. This suggested that they were either outcrosses or unknown mixed seed. The possibility of a double crossover is very low due to the absence of single crossover events in all of mapping populations discussed in the present study; therefore, double crossover events were left out of the analysis.

\section{DISCUSSION}

In the present study, we determined that the rice blast resistance gene $P i$ - $t a$ confers resistance to major pathotypes of the U.S. rice blast pathogen. Continued incorporation of the Pi-ta gene with other major resistance genes and quantitative trait loci into advanced breeding lines is a major focus of rice cultivar improvement in the United States. A pair of DNA primers that specifically amplifies a portion of the susceptible pi-ta allele developed in this study should be able to confirm DNA quality. PCR based markers for the Pi-ta gene developed previously (19) and markers for the recessive pi-ta gene developed in this study can be used to accelerate the introgression of $\mathrm{Pi}$ - $\mathrm{ta}$ into advanced breeding lines by MAS. MAS can identify $R$ genes accurately and is performed independently of environment and pathogen and, thus, reduces costs of physical and human resources for $R$ gene identification. MAS is particularly attractive to rice blast resistance breeding because it can avoid the following problems. (i) The avirulence genes in any uncharacterized $M$. grisea race generally are unknown. Thus, it is difficult to identify $R$ genes using differential $M$. grisea races. (ii) Each $R$ gene triggers a complete resistance to an $M$. grisea race expressing an avirulence gene, thus masking expression of other $R$ genes (35). Tagging Pi-ta using the Pi-ta gene markers should not prevent the identification of other $R$

\section{OSM89 $\quad$ RM155 $\quad$ RM7102}
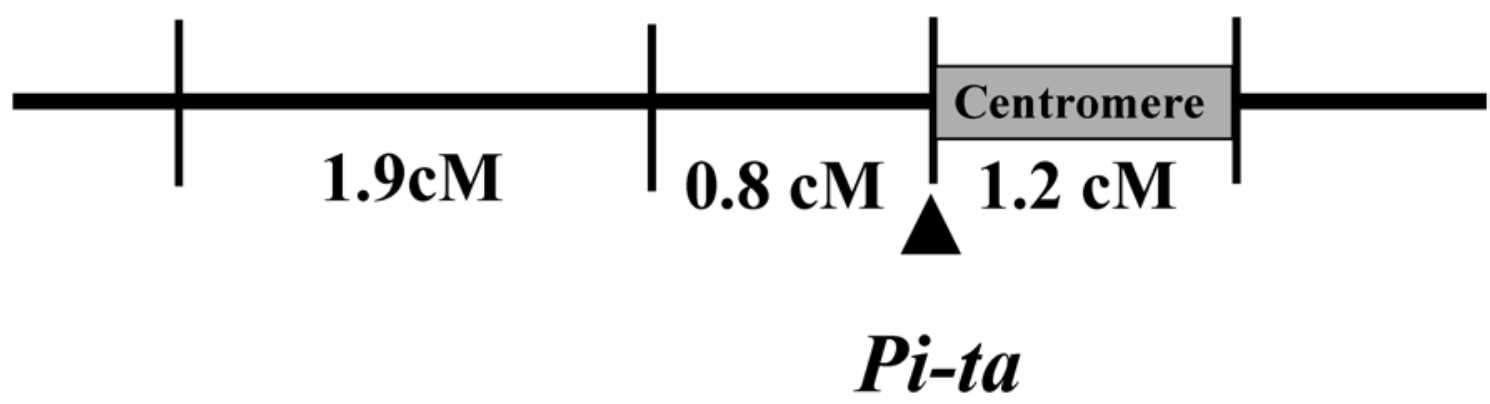

Fig. 2. A fine map of the Pi-ta gene. Simple sequence repeat (SSR) loci near the Pi-ta gene from cv. Kaybonnet using combined data of crosses segregating for resistance to Magnaporthe grisea race IB-49 and presence of the dominant Pi-ta gene marker. Genetic distances in Morgan map units of recombination are displayed on the bottom. Pi-ta was mapped between RM155 and RM7102 near the centromere of chromosome 12 (genetic distances, SSR markers OSM89, RM155, and RM7102 shown). 
genes in rice. (iii) The instability of avirulence genes in $M$. grisea often makes it difficult to confirm $R$ genes (41).

All $P i$ - $t a^{2}$-containing cultivars also contain the Pi-ta genes, as shown in this study and previous studies (2). The Pi-ta gene is located near the centromere of chromosome 12 (2) and recombination suppression observed near the centromere region (5) is a likely explanation for the inability to separate the two. Wang et al. (43) presented preliminary data indicating that a putative $\mathrm{Pi}-\mathrm{ta}^{2}$ gene was located near the Pi-ta gene, near the centromere of chromosome 12. Both genes may be involved in durable resistance observed under field conditions. On the other hand, differences in the resistance spectrum of the Pi-ta gene and the Pi-ta gene also could be due to the different isolates that were used for pathogenicity assays, and the inability of sharing isolates may prohibit a clear understanding of the resistance spectrum of a particular $R$ gene in different laboratories.

Characterization of an endemic avirulent race of $M$. grisea is an important step in predicting the stability of resistance in deployed cultivars. $P i$ - $t a$ confers resistance to IB-49 and IC-17, suggesting that both races contain functional AVR-Pita alleles. A putative product of the AVR-Pita allele from Chinese isolate 0-137 has been shown to interact with the product of $P i$-ta both in vitro and in yeast. Transient expression of both AVR-Pita and Pi-ta in rice seedlings triggered a $P i$-ta-specific cell death (2). The AVR-Pita alleles in IB-49 and IC-17 have been detected by Southern blots and PCR using AVR-Pita-specific DNA primers (Y. Jia, P. Singh, and J. Correll, unpublished data). Analysis of structural and functional relationship of alleles of AVR-Pita from IB-49 and IC17 not only will provide more insight into the protein-protein interaction of Pi-ta/AVR-Pita, but also will address the stability of resistance conferred by $P i$-ta in deployed rice cultivars.

The resistance conferred by $P i$-ta in Katy has been effective commercially since the late 1980s. Typically, resistance mediated by a single $R$ gene is short-lived under field conditions due to the instability of an avirulence gene. Isolates overcoming the Pi-ta gene have been recovered in both fields and laboratories (F. Lee and J. Correll, unpublished data). Therefore, the longevity of Pita effectiveness in the field is likely due to either (i) the fact that conditions for epidemics have been marginal, (ii) M. grisea isolates overcoming the $P i$-ta resistance may be less fit, or (iii) both. It is equally possible that other resistance genes at the Pi-ta locus in Katy also confer resistance to both pathotypes. In the past, seven $R$ genes in a cluster were predicted in Katy to be responsible for resistance $(3,28)$. However, no obvious $R$ gene candidates were identified by sequencing the $850-\mathrm{kb}$ region surrounding $\mathrm{Pi}$ $t a$ (2) and, consequently, no obvious $R$ gene candidates near $P i-t a$ have been inferred from draft sequences of the rice genome (11, 48). Pi-ta is located near the centromere and an unbalanced ratio of physical and genetic distance is not unexpected (5). If the Pi-ta locus is involved in resistance, it is unlikely that other resistance genes are proximal to $P i$-ta.

In the present study, we determined that $\mathrm{Pi}$-ta confers effective resistance to two predominant races of the rice blast fungus in the United States. One way to control blast in the United States is to pyramid other resistance genes with overlapping resistance spectra into $P i$-ta-containing advanced rice breeding lines using marker-assisted $P i$-ta selection. For the long term, establishment of a $\mathrm{Pi}$-ta/AVR-Pita system should lead to a better understanding of molecular mechanisms of the gene-for-gene system. The resulting knowledge should provide better molecular strategies for the control of the rice blast disease.

\section{ACKNOWLEDGMENTS}

We thank the Arkansas Rice Research and Promotion Board for support for this research, C. Flowers and L. Wu for their excellent technical support, H. Bockelman for providing the rice seed, and Y. Xia and $\mathrm{D}$. Wu for supporting $\mathrm{Z}$. Wang's graduate training at the Molecular
Plant Pathology Lab of the USDA-ARS Dale Bumpers National Rice Research Center. M. A. Azam was a fellow of the International Atomic Energy Agency from Bangladesh Institute of Nuclear Agriculture.

\section{LITERATURE CITED}

1. Ayers, N. M., McClung, A. M., Larkin, P. D., Bligh, H. F. J., Jones, C. A., and Park, W. D. 1997. Microsatellites and a single-nucleotide polymorphism differentiate apparent amylose classes in an extended pedigree of US rice germplasm. Theor. Appl. Genet. 94:773-781.

2. Bryan, G. T., Wu, K. S., Farrall, L., Jia, Y., Hershey, H. P., McAdams, S. A., Faulk, K. N., Donaldson, G. K., Tarchini, R., and Valent, B. 2000. A single amino acid difference distinguishes resistant and susceptible alleles of the rice blast resistance gene Pi-ta. Plant Cell 12:2033-2046.

3. Chao, C. T., Moldenhauer, K. A. K., and Ellingboe, A. H. 1999. Genetic analysis of resistance/susceptibility in individual $\mathrm{F}_{3}$ families of rice against strains of Magnaporthe grisea containing different genes for avirulence. Euphytica 109:183-190.

4. Chauhan, R. S., Farman, M. L., Zhang, H. B., and Leong, S. A. 2002. Genetic and physical mapping of a rice blast resistance locus, $\mathrm{Pi}-\mathrm{CO} 39(\mathrm{t})$, that corresponds to the avirulence gene AVR1-CO39 of Magnaporthe grisea. Mol. Gen. Genet. 267:603-612.

5. Chen, M., Presting, G., Barbazuk, W. B., Goicoechea, J. L., Blackmon, B., Fang, G., Kim, H., Frisch, D., Yu, Y., Sun, S., Higingbottom, S., Phimphilai, D., Thurmond, S., Gaudettem, B., Li, P., Liu, J., Hatfield, J., Main, D., Farrar, K., Henderson, C., Barnett, L., Costa, R., Williams, B., Walser, S., Atkins, M., Hall, C., Budiman, M. A., Tomkins, J. P., Luo, M., Bancroft, I., Salse, J., Regad, F., Mohapatra, T., Singh, N. K., Tyagi, A. K., Soderlund, C., Dean, R. A., and Wing, R. A. 2002. An integrated physical and genetic map of the rice genome. Plant Cell 14:537-545.

6. Correll, J. C., Harp, T. L., Guerber, J. C., Zeigler, R. S., Liu, B., Cartwright, R. D., and Lee, F. N. 2000. Characterization of Pyricularia grisea in the United States using independent genetic and molecular markers. Phytopathology 90:1396-1404.

7. Counce, P. A., Keisling, T. C., and Mitchell, A. J. 2000. A uniform, objective, and adaptive system for expressing rice development. Crop Sci. 40:436-443.

8. Dangl, J. L., and Jones, J. D. G. 2001. Plant pathogens and integrated defense response to infection. Nature 411:826-833.

9. Fjellstrom, R. G., McClung, A. M., Shank, A., Marchetti, M. A., Bormans, C., and Park, W. D. 2002. Progress on development of microsatellite markers associated with rice blast resistance genes. (Abstr.) Pages 43-44 in: Proc. 29th Rice Tech. Working Group. Little Rock, AR.

10. Fukuoka, S., and Okuno, K. 2001. QTL analysis and mapping of Pi21, a recessive gene for field resistance to rice blast in Japanese upland rice. Theor. Appl. Genet. 103:185-190.

11. Goff, S., Ricke, D., Lan, T.-H., Presting, G., Wang, R., Dunn, M., Glazebrook, J., Session, A., Oeller, P., and Warma, H. et al. 2002. A draft sequence of the rice genome (Oryza sativa L. ssp. japonica). Science 296:92-100.

12. Hammond-Kosack, K. E., and Jones, J. D. G. 1996. Resistance gene-dependent plant defense responses. Plant Cell 8:1773-1791.

13. Hittalmani, S., Foolad, M., Mew, T., Rodriguez, R., and Huang, N. 1994. Identification of blast resistance gene $P i-2(t)$ in rice plants by flanking DNA markers. Rice Genet. Newsl. 11:144-146.

14. Hittalmani, S., Parco, A., Mew, T., Ziegler, R. S., and Huang, N. 2000. Fine mapping and DNA marker-assisted pyramiding of the three major genes for blast resistance in rice. Theor. Appl. Genet. 100:1121-1128.

15. Imbe, T. 1997. Genetic studies on blast resistance. In: Stabilization of Rice Culture Under Water Stress in the Tropics Utilizing a Broader Spectrum of Genetic Resources. Prog. Rep. IRRI-Japan Project, Tokyo.

16. Jia, Y., Bryan, G. T., Farrall, L., and Valent, B. 2003. Natural variation at the Pi-ta rice blast resistance locus. Phytopathology 93:1452-1459.

17. Jia, Y., McAdams, S. A., Bryan, G. T., Hershey, H. P., and Valent, B. 2000. Direct interaction of resistance gene and avirulence gene products confers rice blast resistance. EMBO J. 19:4004-4014.

18. Jia, Y., Valent, B., and Lee, F. N. 2003. Determination of host resistance responses to Magnaporthe grisea on detached rice leaves using a spot inoculation method. Plant Dis. 87:129-133.

19. Jia, Y., Wang, Z., and Singh, P. 2002. Development of dominant rice blast Pi-ta resistance gene markers. Crop Sci. 42:2145-2149.

20. Kiyosawa, S. 1967. Genetic studies on host-pathogen relationship in the rice blast disease. Pages 137-153 in: Proc. Symp. Rice Disease and Their Control by Growing Resistant Varieties and Other Measures. Tokyo.

21. Kiyosawa, S. 1969. Genetic analysis of rice blast resistance genes of rice cultivar Yashiromochi. Nogyo oyobi Engei (Agric. Hortic.) 44:407408.

22. Kiyosawa, S. 1972. Genetics of blast resistance. Pages 203-225 in: Rice Breeding. IRRI, Manila, the Philippines. 
23. Kiyosawa, S., Mackill, D. J., Bonman, J. M., Tanaka, Y., and Ling, Z. Z. 1986. An attempt of classification of world's rice varieties based on reaction pattern to blast fungus strains. Bull. Natl. Inst. Agrobiol. Resour. 2:13-39.

24. Lee, F. N. 1994. Rice breeding programs, blast epidemics and blast management in the United States. Pages 489-500 in: Rice Blast Disease. R. S. Zeigler, S. A. Leong, and P. S. Teng, eds. CAB International, Wallingford, UK.

25. Manly, K. F., Cudmore, R. H., Jr., and Meer, J. M. 2001. Map Manager QTX, cross-platform for genetic mapping. Mamm. Genome 12:930-932.

26. McCouch, S. R., Nelson, R. J., Tohme, J., and Zeigler, R. S. 1994. Mapping of blast resistance genes in rice. Pages 167-186 in: Rice Blast Disease. R. S. Zeigler, S. A. Leong, and P. S. Teng, eds. CAB International, Wallingford, UK.

27. McCouch, S. R., Teytelman, L., Xu, Y., Lobos, K. B., Clare, K., Walton, M., Fu, B., Maghirang, R., Li, Z., Xing, Y., Zhang, Q., Kono, I., Yano, M., Fjellstrom, R., DeClerck, G., Schneider, D., Cartinhour, S., Ware, D., and Stein, L. 2002. Development and mapping of 2240 new SSR markers for rice (Oryza sativa L.). DNA Res. 9:199-207.

28. Moldenhauer, K. A. K., Bastawisi, A. O., and Lee, F. N. 1992. Inheritance of resistance in rice to races IB-49 and IC-17 of Pyricularia grisea rice blast. Crop Sci. 32:584-588.

29. Moldenhauer, K. A. K., Lee, F. N., Norman. R. J., Helms, R. S., Well, R. H., Dilday, R. H., Rohman, P. C., and Marchetti, M. A. 1990. Registration of 'Katy' rice. Crop Sci. 30:747-748.

30. NAAS (National Agriculture Statistics Service), USDA. 2002. Available online by the U.S. Department of Agriculture.

31. Nakamura, S., Asakawa, S., Ohmido, N., Fukui, K., Shimizu, N., and Kawasaki, S. 1997. Construction of an 800-kb contig in the near-centromeric region of the rice blast resistance gene $P i-t a^{2}$ using a highly representative rice BAC library. Mol. Gen. Genet. 254:611-620.

32. Naqvi, N. I., and Chattoo, B. B. 1996. Development of sequence characterized amplification region (SCAR) based indirect selection method for a dominant blast resistance gene in rice. Genome 39:26-30.

33. Orbach, M. J., Farrall, L., Sweigard, J. A., Chumley, F. G., and Valent, B. 2000. A telomeric avirulence gene determines efficacy for the rice blast resistance gene Pi-ta. Plant Cell 12:2019-2032.

34. Rybka, K., Miyamoto, M., Ando, I., Saito, A., and Kawasaki, S. 1997. High resolution mapping of the indica-derived rice blast resistance gene II. Pi-ta $a^{2}$ and Pi-ta and a consideration of their origin. Mol. PlantMicrobe Interact. 10:517-524.

35. Silue, D., Nottenghem, J. L., and Tharreau, D. 1992. Evidence for a genefor-gene relationship in the Oryza sativa-Magnaporthe grisea pathosystem. Phytopathology 82:577-580.

36. Tabien, R. E., Li, Z., Paterson, A. H., Marchetti, M. A., Stansel, J. W., and Pinson, R. M. 2002. Mapping QTLs for field resistance to the rice pathogen and evaluating their individual and combined utility in improved varieties. Theor. Appl. Genet. 105:313-324.
37. Tabien, R. E., Li, Z., Paterson, A. H., Marchetti, M. A., Stansel, J. W., Pinson, R. M., and Park, W. D. 2000. Mapping of four major rice blast resistance genes from 'Lemont' and 'Teqing' and evaluation of their combinatorial effect for field resistance. Theor. Appl. Genet. 101:1215-1225.

38. Takken, F. L. W., and Joosten, M. H. A. J. 2000. Plant resistance genes: Their structure, function and evolution. Eur. J. Plant Pathol. 106:699-713.

39. Tanksley, S. D., Fulton, T. M., and McCouch, S. R. 1993. Linkage map of rice (Oryza sativa) $(2 \mathrm{~N}=24)$. Pages 6.61-6.79 in: Genetic Maps of Complex Genome. Book 6. Plants. J. O’Brien, ed. Cold Spring Harbor Laboratory, Cold Spring Harbor, NY.

40. Temnykh, S., Park, W. D., Ayres, N., Cartinhour, S., Hauck, N., Lipovich, L., Cho, Y. G., Ishii, T., and McCouch, S. R. 2000. Mapping and genome organization of microsatellite sequences in rice (Oryza sativa L.). Theor. Appl. Genet. 100:697-712.

41. Valent, B. 1997. The rice blast fungus, Magnaporthe grisea. Pages 37-54 in: Plant Relationships. The Mycota V Part B. G. C. Carroll and P. Tudzynoski, eds. Springer-Verlag, Berlin, Heidelberg.

42. Valent, B., Farrall, L., and Chumley, F. G. 1991. Magnaporthe grisea genes for pathogenicity and virulence identified through a series of backcrosses. Genetics 127:87-101.

43. Wang, C., Hirano, K., and Kawasaki, S. 2002. Cloning of Pi-ta ${ }^{2}$ in the centromeric region of Chromosome 12 with HEGS: High efficiency genome scanning. Page 25 in: 3rd Int. Rice Blast Conf., Tsukuba, Japan.

44. Wang, G. L., Mackill, D. J., Bonman, J. M., McCouch, S. R., Champoux, M. C., and Nelson, R. L. 1994. RFLP mapping of genes conferring complete and partial resistance to blast in a durably resistant rice cultivar. Genetics 136:1421-1434.

45. Wang, Z.-X., Yano, M., Yamanouchi, U., Iwamoto, M., Monna, L., Hayasaka, H., Katayose, Y., and Sasaki, T. 1999. The Pi-b gene for rice blast resistance belongs to the nucleotide binding and leucine-rich repeat class of plant disease resistance genes. Plant J. 19:55-64.

46. Wu, J., Maehara, T., Shimokawa, T., Yamamoto, S., Harada, C., Takazaki, Y., Ono, N., Mukai, Y., Koike, K., Yazaki, J., Fuji, F., Shomura, A., Ando, T., Kono, I., Waki, K., Yamamoto, K., Yano, M., Matsumoto, T., and Sasaki, T. 2002. A comprehensive rice transcript map containing 6591 expressed sequence tag sites. Plant Cell 14:525-535.

47. Xia, J. Q., Correll, J. C., Lee, F. N., and Rhoads, D. D. 2000. Regional population diversity of Pyricularia grisea in Arkansas. Plant Dis. 84:877884.

48. Yu, J., Hu, S., Wang, J., Wong, G., Li, S., Liu, B., Deng, Y., Dai, L., Zhou, Y., and Zhang, X. et al. 2002. A draft sequence of the rice genome (Oryza sativa L. ssp. indica). Science 296:79-92.

49. Yu, Z. H., Mackill, D. J., Bonman, J. M., and Tanksley, S. D. 1991 Molecular mapping of genes for resistance to rice blast (Pyricularia grisea Sacc.). Theor. Appl. Genet. 81:471-476.

50. Zenbayashi, K., Ashizawa, T., Tani, T., and Koizumi, S. 2002. Mapping of the QTL conferring partial resistance to leaf blast in rice cultivar Chubu 32. Theor. Appl. Genet. 104:547-552. 